УДК 379.85:625.7

JEL L 83, L 92, Z 32

DOI 10.31375/2226-1915-2021-2-132-143

СУЧАСНЕ БУДІВНИЦТВО

I РЕМОНТ ДОРІГ У ЛЬВІВСЬКІЙ ОБЛАСТІ ЯК ЧИННИК РОЗВИТКУ ТУРИЗМУ

\section{T.B. Періг}

асистент кафедри історії України,

економічної теорії та туризму

tetianaperih647@gmail.com

ORCID: https://orcid.org/0000-0003-2333-6183

Львівський начіональний університет ветеринарної медицини та біотехнологій імені С.3. Гжицького, Львів, Украӥна

Анотація. Стаття розвиває дослідження, пов'язані з впливом транспортної інфраструктури на розвиток туристичної галузі в Україні. Метою дослідження є аналіз сучасного будівництва і ремонту автомобільних доріг на Львівщині в контексті перспектив розвитку туризму в регіоні. Встановлено, що, розпочинаючи, з 2015 р. у Львівській області суттево зросли обсяги ремонту та будівниитва автомобільних доріг, сумарно за 2015-2020 рр. відремонтовано 685 км доріг. Внаслідок иього суттєво поліпиилася транспортна доступність низки відомих туристичних і курортних иентрів області: Золочева, Немирова, Сколе, Славського, Трускавия й ін. Покращився також автомобільний зв'язок Львівської області з іншими туристичними регіонами Украӥни: Закарпаттям (Ужгород, Мукачеве, гірські й рівнинні курорти), Івано-Франківщиною (Івано-Франківськ, Рогатин, Яремче, курорт Буковель), Тернопільщиною (обласний иентр). Поліпшився стан доріг прилеглих до кордону з Республікою Польща. Кочти на ремонт з'явилися головно завдяки проведенню урядом з 2015 р. експерименту з використання коштів понадпланових митних надходжень на фінансування дорожньої інфраструктури, державній програмі «Велике будівництво» у 2020 р., а також завдяки кредиту Республіки Польща на капітальний ремонт прикордонних доріг. Сумар не фінансу-вання ремонту доріг у 2021 р. заплановано у обсязі близько 1 млн. грн. Усе це має суттєво пришвидшити розвиток передусім внутріш-нього туризму в Західній Украӥні.

Ключові слова: туризм, курорти, ремонт доріг, регіон, транспортна інфраструктура, фінансування, доступність.

(C) Періг Т.В., 2021
УДК 379.85:625.7

JEL L 83, L 92, Z 32

DOI 10.31375/2226-1915-2021-2-132-143

\section{СОВРЕМЕННОЕ СТРОИТЕЛЬСТВО И РЕМОНТ ДОРОГ В ЛЬВОВСКОЙ ОБЛАСТИ КАК ФАКТОР РАЗВИТИЯ ТУРИЗМА}

\section{Т.В. Периг}

ассистент кафедры истории Украины, экономической теории и туризма tetianaperih647@gmail.com

ORCID: https://orcid.org/0000-0003-2333-6183

\footnotetext{
Львовский национальный университет ветеринарной медицины и биотехнологий имени С.3. Гжицкого, Украина
}

Аннотация. Статья развивает исследования, связанные с влиянием транспортной инфраструктуры на развитие туристической отрасли в Украине. Целью исследования является анализ современного строчтельства и ремонта автомобильных дорог в Львовской области в контексте перспектив развития туризма в регионе. Установлено, что начиная с 2015 2. в Львовской области существенно выросли объемы строительства и ремонта автомобильных дорог, суммарно за 2015-2020 г2. отремонтировано 685 км. В результате существенно улучшилась транспортная доступность ряда известных туристических и курортных иентров области: Золочев, Немиров, Сколе, Славское, Трускавеч и др. Улучшилась также автомобильная связь Львовской области с другими туристическими регионами Украинь: Закарпатьем (Ужгород, Мукачево, горные и равнинные курорты), Ивано-Франковской областью (Ивано-Франковск, Рогатин, Яремче, курорт Буковель,), Тернопольскою областью (областной центр). Улучшилось состояние дорог прилегающих к границе c Республикой Польша. Средства на ремонт появились в основном благодаря проведению правительством с 2015 г. эксперимента по использованию средств от сверхплановых таможенных поступлений на финансирование дорожной инфраструктуры, государственной программе «Большое строительство» в 2020 г., а также благодаря кредиту Республики Польша на капитальный ремонт пограничных дорог. Суммарное финансирование ремонта дорог в 2021 запланировано в объеме около 1 млн. грн. Все это должно существенно ускорить развитие прежде всего внутреннего туризма в Западной Украине.

Ключевые слова: туризм, курорты, ремонт дорог, регион, транспортная инфраструктура, финансирование, доступность. 
UDC 379.85: 625.7

JEL L 83, L 92, Z 32

DOI 10.31375/2226-1915-2021-2-132-143

\title{
MODERN CONSTRUCTION AND RECONDITIONING OF THE HIGHWAYS IN LVIV DISTRICT AS THE MAIN FACTOR OF TOURISM DEVELOPMENT
}

\author{
Tetiana Perih \\ Assistant at the Department of History of Ukraine, \\ Economic Theory and Tourism \\ tetianaperih647@gmail.com \\ ORCID: https://orcid.org/0000-0003-2333-6183 \\ Lviv National Stepan Gzhytsky University \\ of Veterinary Medicine and Biotechnology, Lviv, Ukraine
}

\begin{abstract}
In the process of overcoming the consequences of COVID-19 pandemic in Ukraine and in the whole world, we should expect streaming tourists flow retrieval and for some time more prioritised will be domestic tourism. It will greatly contribute acceleration of tourism restoration and improvement of tourist's condition and concomitant infrastructure, including highways.

This article develops researches about influence of transport infrastructure on tourism development in Ukraine. The subject of a research is Lviv district. It is one of the most attractive districts in Ukraine. The purpose of research is to analyse modern construction and reconditioning of the highways in Lviv district in context of promising development of tourism in the region. The basis of information for article was statistical materials, "Ukravtodor» data and literary sources. Method of literature, statistical and cartographic analysis was used.

From the beginning of 2015, it was found that the amount of construction and reconditioning of the highways for period from 2015 to 2020 has been increased, in general, $685 \mathrm{~km}$ of highways were repaired. Because of that transport accessibility to some famous tourists places and resorts such as: Zolochyv, Nemyriv, Skole, Slavsk, Truskavets etc. significantly had been increased. Same improvement we may observe for transport joining Lviv district with others districts of Ukraine such as Zakarpattya (Uzgorod, Mukacheve, mountain and plain resorts), Ivano-Frankivsk (Bukovel resort, Ivano-Frankivsk, Rogatyn, Yaremche), Ternopil district (regional centre), also there is improvement of highways conditions near the board of Republic of Poland. The finances for reconstructions emerged after governments experiment in 2015 of financing transport infrastructure from unscheduled customer revenues, state program "The great reconstruction» in 2020 as well as the credit of Republic of Poland for repair if boarder roads. The main task in 2021 is to start construct northern bypass way around Lviv. All those measures must significantly accelerate first of all domestic tourism in Western Ukraine.
\end{abstract}

Keywords: tourism, resorts, highways reconstruction, region, transport infrastructure, financing, accessibility.

Постановка проблеми. Впродовж останніх десятиліть туризм залишається однією 3 найприбутковіших галузей світового господарства. В сучасних умовах глобалізації він сприяє вирішенню багатьох важливих соціально-економічних проблем.
Особливістю туристичного сектору є те, що він сприяє підвищенню зайнятості населення, розвитку ринкових відносин, міжнародної співпраці, залученню громадян до знань про природну, історичну та культурну спадщину, а також підтримці еколо- 
гічного балансу. Пріоритетний розвиток туризму в Україні позитивно впливає на економічне та соціальне становище країни, стимулює інші важливі галузі економіки, сприяе зміцненню позитивного іміджу держави у світі.

Ефективний розвиток туризму не можливий без якісної туристичної та супутньої інфраструктури, в тому числі транспортної. У сучасних наукових дослідженнях, вивчаючи транспортну інфраструктуру, здебільшого iii розглядають 3 погляду наявності й якості засобів туристичного транспорту, особливостей перевезення тощо, на питання стану дорожньої інфраструктури звертається менше уваги. У процесі подолання наслідків пандемії коронавірусу COVID-19 в Україні й світі варто очікувати швидкого відновлення туристичних потоків, причому пріоритетним певний період буде внутрішній туризм. Значно сприятиме швидкому відновленню туризму збереження та поліпшення належного стану інфраструктури, в тому числі автомобільних доріг.

Огляд останніх досліджень і публікацій. В Україні публікацій, що поєднують питання розвитку транспорту й стану автомобільної інфраструктури небагато. В останні роки декілька статей опублікувала О.М. Залузіна, самостійно або у співавторстві [1-3], зокрема, одна 3 них, у співавторстві з Р.О. Черниш, стосується питань будівництва автомобільних доріг в аспекті туризмології [2]. М.П. Бутко i Н.О. Алєшугіна здійснили дослідження розвитку мережі шляхів автомобільного сполучення України та ії роль у зміцненні туристичного потенціалу держави [4].
Загалом небагато публікацій, пов'язаних 3 дорожнім будівництвом та ремонтом і різноманітними аспектами розвитку туризму, $\epsilon$ в англомовній науковій літературі. В 2020 p. у журналі «Tourism Management» колектив авторів з Китаю і Пакистану опублікував статтю про розвиток дорожньої і транспортної інфраструктури та підтримка туризму в громадах в контексті реалізації багатомільярдного мегапроекту китайсько-пакистанського економічного коридору [5]. У процесі дослідження було використано дані онлайн-опитування 350 осіб, які живуть уздовж маршруту економічного коридору.

Науковці з Філліпін Й. Мірабуено і Е. Юйуіко (Mirabueno \& Yujuico, 2014) дослідили питання координації роботи й співробітництва різних державних і приватних органів у процесі вирішення питань поліпшення дорожньої інфраструктури 3 метою розвитку туризму [6]. Дослідники з Норвегії Й. Денстадлі і Й. Якобсен (Den-stadli, \& Jacobsen, 2011) встановили вплив такого фактору як мальовничість доріг, придорожніх ландшафтів у процесі вибору маршруту туристичної подорожі [7]. Науковці з Норвегії й Швеції (Antonson \&J. Jacobsen, 2014) порівняли особливості планування дорожніх туристичних маршрутів у зазначених країнах [8]. Іспанські вчені Й. Роселло і О. Саенс де Мiера встановили як туризм впливає на нещасні випадки що трапляються на автомобільних дорогах на Балеарських островах (Rosselló, O. Saenz-deMiera, 2011) [9].

Безпосередньо публікацій, які б пов'язали активне будівництво й ремонт доріг, які введуться в Україні в 
DEVELOPMENT OF MANAGEMENT

AND ENTREPRENEURSHIP METHODS ON TRANSPORT, № 2 (75), 2021
РОЗВИТОК МЕТОДІВ

УПРАВЛІННЯ ТА ГОСПОДАРЮВАННЯ

НА ТРАНСПОРТІ, № 2 (75), 2021 останні роки, 3 питаннями розвитку туризму в державі немає.

Завдання дослідження. Метою статті є аналіз сучасного процесу будівництва і ремонту доріг у Львівській області в контексті перспектив розвитку туризму в регіоні.

Основний матеріал дослідження. Сучасний етап економічного розвитку України визначається реалізацією економічної політики, спрямованої на зближення з Свропейським Союзом (після підписання угоди про асоціацію), що, включає виконання великої кількості завдань, у тому числі забезпечення пріоритетного розвитку рекреаційно-туристичних зв'язків між країнами. Це пов'язано насамперед із глобалізацією економіки, підвищенням рівня життя в економічно розвинених країнах, а також великими інвестиціями в привабливі туристичні регіони та збільшенням мобільності населення.

Однією з областей України, які володіють найбільшим туристичним потенціалом, є Львівська область. Туристична галузь традиційно вважається однією із спеціалізацій бізнесу на Львівщині. Як туристично-рекреаційний регіон, область відрізняється великою кількістю різноманітних туристичних ресурсів, сучасною матеріально-технічною базою туристичної галузі, наявністю доступної та надійної інформаціє про регіон, що відповідає потребам туристів і спрямована на досягнення максимального соціально-економічного ефекту. Туризм в останні два десятиліття став для Львівщини своєрідним «спасінням» від численних економічних проблем. За допомогою туризму багатьом жителям області вдалося не лише побороти безробіття, а й досягти високих результатів у підприємництві.

Важливим фактором, що сприяє розвитку туризму в регіоні $є$ доволі високий рівень розвитку транспортної сфери. Завдяки своєму вигідному геополітичному положенню транспортна галузь Львівської області забезпечує значні валютні надходження до бюджету нашої країни. 3 досвіду розвинених країн відомий великий вплив транспортної інфраструктури на зростання економіки країни. Відомо чимало прикладів, коли під час економічної кризи, уряди ряду країн встановлювали пріоритетним курс на будівництво доріг, вирішуючи передусім проблему безробіття. В результаті країни ефективно долали кризи, підвищуючи рівень розвитку економіки та отримували розвинену мережу доріг [10].

Якісні автомобільні дороги $\epsilon$ однією 3 найактуальніших проблем сучасного туризму, оскільки завдяки хорошим дорогам та прокладеним ними маршрутам туристам може потрапити до туристичного центру без зайвих проблем та фінансових і моральних витрат. На сьогоднішній день Львівська область значно краще забезпечена магістралями, порівняно 3 іншими західними областям, їхня сумарна протяжність близько 8 тис. кілометрів [11]. Для інших регіонів Західної України цей показник становить 3-4 тис. км. Однак, з іншого боку Львівщина має суттєво більшу площу та кількість населення, ніж сусідні області. Крім автомобільних доріг загального користування, Львівська область має достатньо розвинену придорожню інфраструктуру. 
DEVELOPMENT OF MANAGEMENT

AND ENTREPRENEURSHIP METHODS ON TRANSPORT, № 2 (75), 2021
РОЗВИТОК МЕТОДІВ

УПРАВЛІННЯ ТА ГОСПОДАРЮВАННЯ

НА ТРАНСПОРТІ, № 2 (75), 2021
Незважаючи на відносно високий стан розвитку окремих складових дорожньої інфраструктури, іiї загальний стан ще не повністю відповідає стандартам сучасної економіки. Знач-

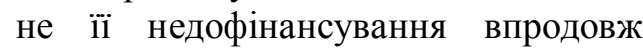
багатьох років призвело до низки проблем: незадовільний експлуатаційний стан більшості місцевих доріг; окремі ділянки існуючої мережі державних та місцевих доріг проходять безпосередньо територією населених пунктів, що порушує рівномірність транспортного потоку, збільшує аварійність, зменшує швидкість руху, погіршує екологію. Існуючі транспортні й експлуатаційні показники доріг визначають низьку робочу швидкість транспортних засобів, високі витрати пального та мастильних матеріалів та високу частку транспортної складової в собівартості продукції. Внаслідок неналежного стану транспортні витрати в 1,5 рази, а споживання пального на 30 \% вищі, ніж аналогічні показники в розвинених країнах.

Розвиток автомобільних доріг у Львівській області $є$ доволі нерівномірним. Найгірша ситуація склалася у гірській частині регіону, в прикордонних районах, а також на півночі області. Важливою причиною незадовільного стану автодоріг у гірській частині області є об'єктивні труднощі будівництва й ремонту доріг у місцевості із складним рельєфом, а саме необхідності витрачати значно більше коштів, порівняно з рівнинними територіями. Незадовільний стан доріг $\epsilon$ також у низці прикордонних районів Львівщини. Він зумовлений тим, що в період існування СРСР, кордон виконував головну бар'єрну функцію. У результаті, поселення, розташовані поблизу кордону, занепадали, належної уваги дорожній інфраструктурі не надавалося. Тому чимало атракційних 3 погляду розвитку туризму міст і селищ не мали належного транспортного доступу: Белз, Немирів, Хирів, Добромиль. Важливою проблемою залишається також незадовільний стан багатьох доріг місцевого значення. 3 огляду на те, що у Львівській області значна частина туристичних пам'яток, зокрема, цікавих історико-культурних об'єктів державного значення, знаходяться у невеликих містах та селища, відсутність належного доступу до них суттєво стримує розвиток внутрішнього туризму.

В останні п'ять років ситуація суттєво поліпшилася. Розпочинаючи 3 2015 р. у Львівській області зросли обсяги будівництва та ремонту автомобільних доріг, сумарно за 20152020 рр. відремонтовано 685 км доріг (рис. 1).

Головних джерел для здійснення ремонтних і будівельних робіт було три. По-перше, це кошти, зумовлені прийняттям Постанови Кабінету Мiністрів України № 726 від 16 вересня 2015 р. «Про проведення експерименту в Одеській, Волинській, Львівській та Чернівецькій областях 3 фінансового забезпечення реконструкції, поточного ремонту автомобільних доріг загального користування державного значення» [13]. Відповідно до цього документу на період проведення експерименту було встановлено, що $50 \%$ перевиконання індикативних показників надходжень митних платежів зараховувалося до обласних бюджетів на потреби ремонту автодоріг. 
DEVELOPMENT OF MANAGEMENT

AND ENTREPRENEURSHIP METHODS

ON TRANSPORT, № 2 (75), 2021
РОЗВИТОК МЕТОДІВ

УПРАВЛІННЯ ТА ГОСПОДАРЮВАННЯ

НА ТРАНСПОРТІ, № 2 (75), 2021

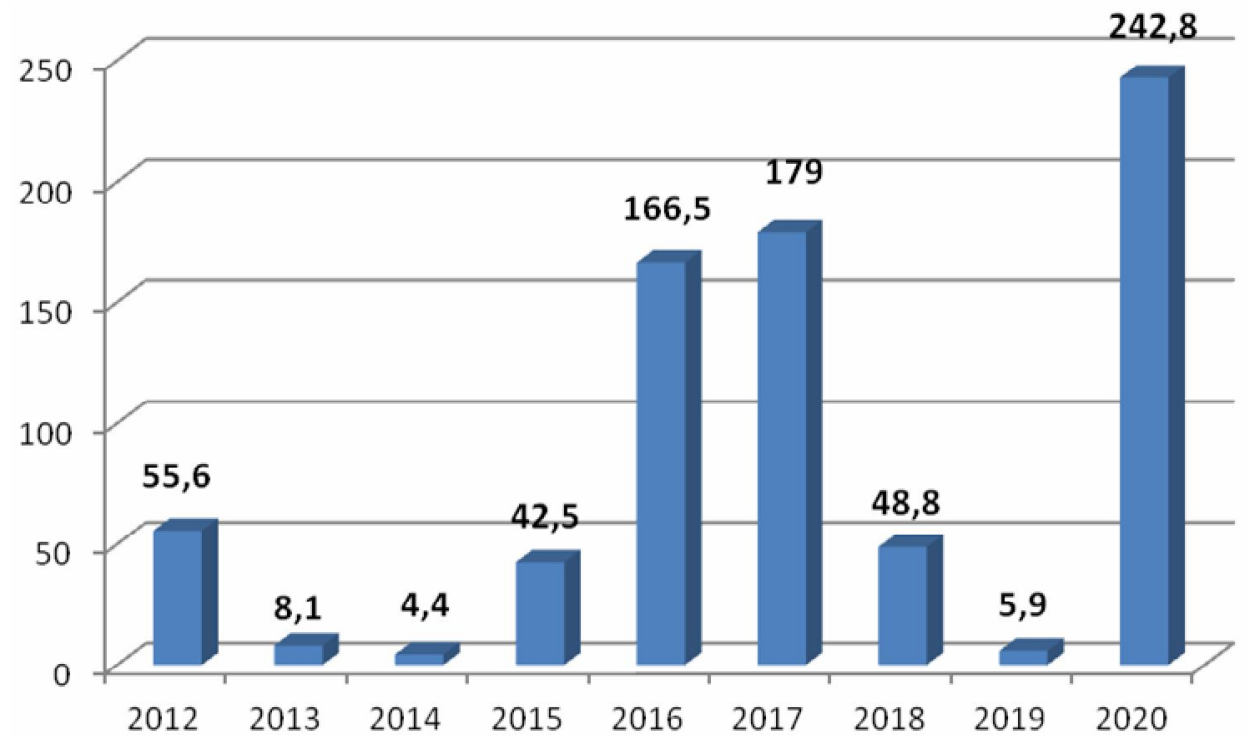

Рис. 1. Обсяги ремонту автомобільних доріг у Львівській області в 2012-2020 pp.

Джерело: сформовано автором на основі [12]

Головне, внаслідок прийняття постанови вже в 2015 р. у області, попри те, що у державі все ще тривала економічна криза, зумовлена політичними подіями, було відремонтовано майже в 10 разів більше доріг, порівняно 3 попереднім роком, 42,5 км, проти 4,4 км у 2014 р. В 2016 р. довжина відремонтованих доріг зросла ще у 4 рази порівняно з 2015 p.

Серед найважливіших доріг, які було відремонтовано за рахунок перевиконання митних платежів, виділимо такі важливі для розвитку туризму:

1. Автошлях міжнародного значення М-19, на ділянці Львів-Тернопіль. Ця дорога з'єднує два туристично-привабливих міста, Львів і Тернопіль, на півдорозі також розташовано Золочів, в якому знаходиться відомий в Україні замок, частина туристичного маршруту «Золота підкова Львівщини» (рис. 2).

2. Автошлях національного значення Н-13, Львів-Самбір-Ужгород, на відтинку Самбір - адміністративний кордон із Закарпатською областю. Цей шлях об'єднує два великих туристичних регіони України Львівщину й Закарпаття, перетинає Українські Карпати, проходить мальовничими гірськими краєвидами.

3. Автошлях національного значення Н-09, Мукачево-Рахів-Богородчани-Івано-Франківськ-Рогатин-Бібрка-Львів. Його відремонтовано на ділянці Львів-Бібрка-Рогатин. Це найкоротший автомобільний шлях зі Львова на Передкарпаття до ІваноФранківська, i далі - до гірських курортів Буковель і Драгобрат. 


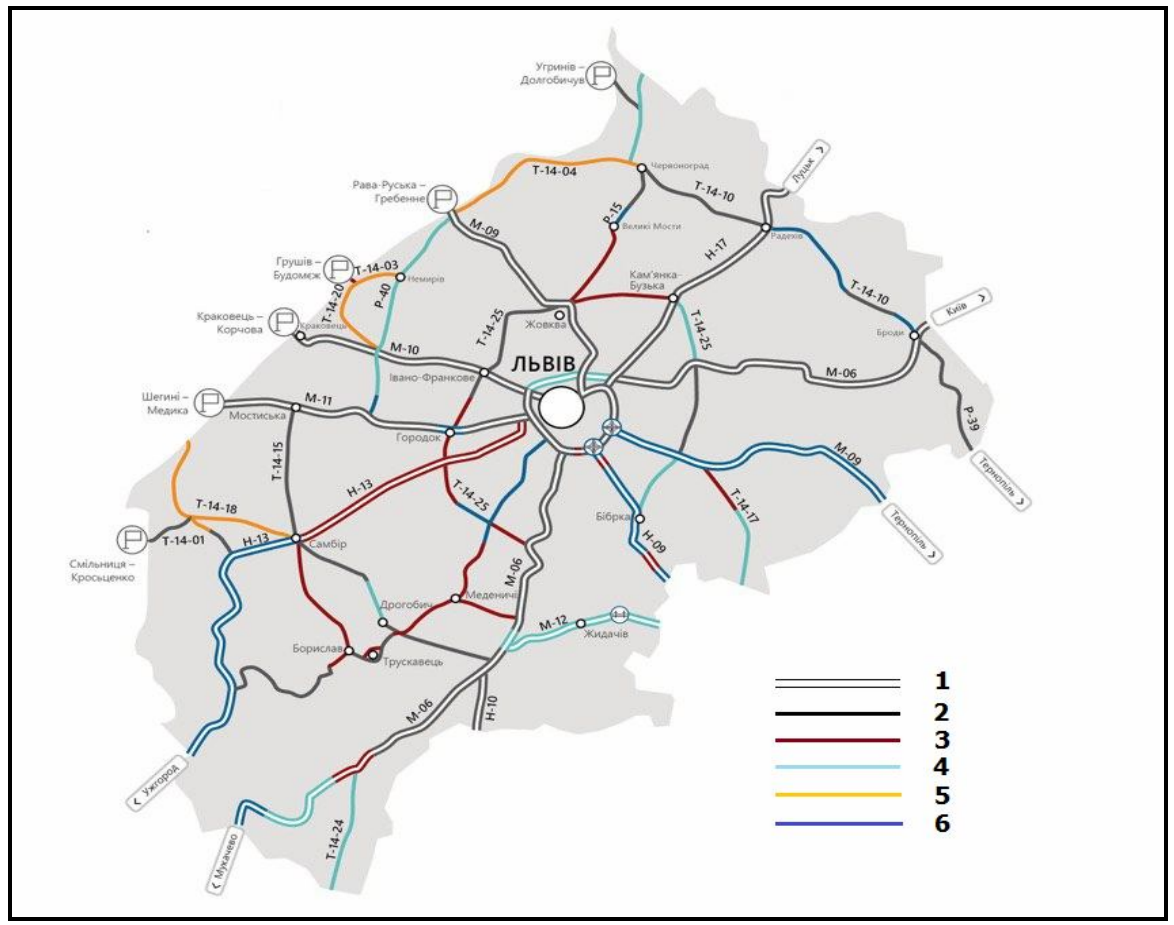

Рис. 2. Ремонт доріг у Львівській області в 2015-2020 рр.

\section{Умовні позначення:}

$$
1 \text {-міжнародні та національні шляхи; }
$$

2 - регіональні й територіальні (місцеві) шляхи; 3 - дороги відремонтовані у 2020 р. за кошти Дорожнього фонду; 4 - дороги, ремонт яких заплановано у 2021 p.; 5 - дороги відремонтована за кошти кредиту Республіки Польща;

$$
6 \text { - дороги відремонтовані до } 2020 \text { р. }
$$

\section{Джерело: сформовано автором на основі [12].}

Друге важливе джерело фінансування ремонту доріг в останні роки - це кредит Республіки Польща на ремонт прикордонних доріг. Оновлення доріг відбувається у рамках реалізації Програми «Розбудова прикордонної дорожньої інфраструктури на підходах до пунктів пропуску на українсько-польському кордоні у рамках Договору між Урядом України та Урядом Республіки Польща про надання кредиту на умовах пов'язаної допомоги від 09.09.2015 року». Загальна сума кредиту становить 58 млн. євро на ремонт п'яти об'єктів Львівщини та однієї дороги у Волинській області [14]. Внаслідок цього кредиту вдалося відремонтувати дороги, що 
DEVELOPMENT OF MANAGEMENT

AND ENTREPRENEURSHIP METHODS ON TRANSPORT, № 2 (75), 2021
РОЗВИТОК МЕТОДІВ

УПРАВЛІННЯ ТА ГОСПОДАРЮВАННЯ

НА ТРАНСПОРТІ, № 2 (75), 2021 ведуть до важливих невеликих турис-тичних центрів 3 цікавими історикотуристичними ресурсами (Белз, Добромиль, Хирів), а також поліпшити стан транспортного сполучення 3 бальнеологічним курортом Немирів (див. рис. 2).

Третє джерело коштів на ремонт та будівництво доріг, яке з'явилося у 2020 р., - це державна програма «Велике будівництво», ініційована президентом України. Внаслідок реалізації цієї програми у Львівській області вдалося відремонтувати ще одну ділянку автошляху національного значення Н-13 на відтинку ЛьвівСамбір, а також, що дуже важливо, відремонтовано декілька автошляхів територіального (місцевого) значення, які поліпшили автомобільне сполучення 3 такими важливими туристичними центрами як Городок, Дрогобич, Борислав, Трускавець, Жовква (див. рис. 2).

Виділення значних коштів на ремонт і будівництво автодоріг в Україні передбачено й у 2021 p. На Львівщині на ремонт доріг у цей рік заплановано виділити 3 Державного дорожнього фонду 891,5 млн. грн. Крім цього, 3 обласного бюджету на ремонт доріг планують витратити 150-200 млн. грн. [15].

Одним 3 найважливіших завдань 2021 р. є початок будівництва північної об’їзної дороги навколо Львова, що завершить створення автомобільного кільця навколо обласного центра. Будівництво кільцевих доріг зазвичай супроводжується також появою вздовж них численних об'єктів готельної інфраструктури, а також ресторанних закладів, які використовують водії та туристи. Ще один пріо- ритет - це завершення ремонту автомобільної траси Р-15 на півночі області, в напрямку до адміністративного кордону з Волинською областю. Ця траса важлива тому, що вона $\epsilon$ найкоротшим напрямком зі Львова до туристичного регіону Шацьких озер у Волинській області. Шацькі озера традиційно використовує населення Львова та інших обласних центрів i великих міст Західної України як певну альтернативу приморським курортам Чорного та Азовського морів. Туристична роль Шацьких озер суттєво зросла з 2014 р., після незаконної анексії Криму Росією.

Якщо будуть виконані всі завдання, спрямовані на поліпшення існуючої ситуації в дорожній інфраструктурі Львівської області, вже в найближчі роки повинні проявлятися позитивні результати в соціальному, економічному та екологічному вимірах розвитку області, в тому числі у сфері туризму. Це сприятиме появі нових туристичних продуктів, створенню додаткових робочих місць як у туризмі, так супутніх сферах, покращить якість туристично-рекреаційних послуг, розширить спектр послуг i збільшить щорічний приплив внутрішніх та іноземних туристів.

Висновки. Львівщина об'єктивно відповідає усім вимогам для інтенсивного розвитку внутрішнього та закордонного туризму: особливості географічного положення та рельєфу, сприятливий клімат, багатство природних, історичних, культурних та туристичних можливостей дозвілля тощо. Однак існує низка факторів, які заважають ефективному розвитку цього виду діяльності, в тому числі 
неналежний стан багатьох автомобільних доріг.

Розпочинаючи 32015 р. у Львівській області суттєво зросли обсяги будівництва та ремонту автомобільних доріг. Внаслідок цього суттєво поліпшилася транспортна доступність низки відомих туристичних і курортних центрів області. Значно покращився також автомобільний зв'язок Львівської області з іншими туристичними регіонами України, Закарпаттям, Івано-Франківщиною, Тернопільщиною, поліпшився стан доріг прилеглих до кордону 3 Республікою Польща. Кошти на ремонт з'явилися завдяки проведенню урядом 32015 р. експерименту 3 використання коштів понадпланових митних надходжень на фінансування дорожньої інфраструктури, державній програмі «Велике будівництво» у 2020 р., а також завдяки кредиту Республіки Польща на капітальний ремонт прикордонних доріг. Головне завдання 2021 р. початок будівництва північної об'їзної дороги навколо Львова. Усі ці заходи мають суттєво пришвидшити розвиток передусім внутрішнього туризму в Західній Україні.

Перспективи подальших досліджень пов' язані передусім з розробкою нових туристичних маршрутів і туристичних продуктів, врахуванням поліпшення стану дорожньої інфраструктури в регіоні. Інший перспективний напрямок дослідження пов'язаний 3 можливостями будівництва нових об'єктів готельної та ресторанної інфраструктури вздовж відремонтованих автошляхів.

\section{ЛIТЕРАТУРА}

1. Залунина О.М. Строительство туристической инфраструктуры и его роль в развитии территории // Причорноморські економічні студї. 2017. № 22. C. 51-59.

2. Залуніна О.М., Черниш Р.О. Будівнищтво автомобільних доріг в аспекті туризмології // Економіка і суспільство. Вип 15. 2018. С. 124-129.

3. Zalunina O.M. Intersectoral balance of construction complex as a factor of territory development // International Journal of Modern Research in Engineering and Technology. 2018. Vol. 3. Issue 1.P.68-74.

4. Бутко М.П., Алєшугіна Н.О. Розвиток мережі иляхів автомобільного сполучення та ї̈ роль у зміцненні туристичного потенціалу України // Регіональна економіка. 2011. № 2. C. 23-33. URL: http://nbuv.gov.ual UJRN/regek_20112_5.

5. Kanwal S., Rasheed M.I., Pitafi A.H., Pitafi A., Ren M. Road and transportin frastructured evelopment and community support for tourism: The role of perceived benefits, and community satisfaction // Tourism Management. Vol. 77. 2020, 104014. DOI: 10.1016/j.tourman.2019.104014 
6. Mirabueno J., Yujuico E., Paving the way for Philippine tourism viainter agency collaboration on road networks // TransportPolicy. Vol. 36. 2014. P. 306315.DOI: 10.1016/j.tranpol.2014.10.002.

7. Denstadli J.M, Jacobsen J.Kr. The long and winding roads: Perceived quality of scenic tourism routes // Tourism Management. Vol. 32. Issue 4. $2011 . \quad P$. 780-789. DOI: 10.1016/j.tourman.2010.06.014.

8. Antonson H., Jacobsen J. Kr. St. Tourism development strategy or just brown signage? Comparing road administration policies and designation procedures for official tourism routes in two Scandinavian countries // Land Use Policy. Vol. 36. 2014. P. 342-350. DOI: 10.1016/j.landusepol.2013.09.003.

9. Rosselló J., Saenz-de-Miera O. Road accidents and tourism: The case of the Balearic Islands (Spain) // AccidentAnalysis\&Prevention. Vol. 43. Issue 3, 2011. - P. 675-683.

10. Божук T.I. Рекреаиійно-туристичні дестинаиї: теорія, методологія, практика: автореф. дис. д-ра геогр. наук: 11.00.11. Львів, 2014. 40 с.

11. Клапчук О.О. Туристично-рекреачійні ресурси Львівської області: терито-ріальна диференціація, оцінка, напрямки використання: автореф. ... дис. канд. геогр. наук: 11.00.02. Л., 2011. 20 с.

12. Амбітний план ремонту доріг у 2020 рочі на Львівщині // Укравтодор. Служба автомобільних доріг у Львівській області [Електронний ресурс]. Режим достуny: https://lv.ukravtodor.gov.ua/press/news/ambitnyi_plan_remontu_dorih_u_2020_rotsi_na_lvivshchyni.html

13. Постанова Кабінету Міністрів Украйни №726 від 16 вересня 2015 року «Про проведення експерименту в Одеській, Волинській, Львівській та Чернівецькій областях з фінансового забезпечення реконструкиії, поточного ремонту автомобільних доріг загального користування державного значення»// Верховна Рада України. URL:https://zakon.rada.gov.ua/laws/ show/726-2015-\%D0\%BF\#Text

14. «Польський кредит» - реалізація Контракту // Укравтодор. Служба автомобільних доріг у Львівській області. URL:https://lv.ukravtodor.gov.ua/ press/news/polskyi_kredyt_realizatsiia_kontraktu.html

15. На ремонт доріг Львівщини иьогоріч витратять майже 1 млрд грн. // Zaxid.net. URL: https://zaxid.net/na_remont_dorig_lvivshhini_tsogorich_vitratyat_mayzhe_1_mlrd_grn_spisok_n1513272

\section{REFERENCES}

1.Zalunina, O. M. (2017). Stroitel'stvo turisticheskoj infrastruktury i ego rol'v razvitii territorii [Construction of tourism infrastructure and its role in the development of the territory]. Prychornomorski ekonomichni studii, 22, 51-59. Retrieved from:http://www.bses.in.ua/journals/2017/22_2017/9.pdf[in Russian].

2. Zalunina O. M., Chernysh R. O. (2018). Budivnytstvo avtomobilnykh dorih v aspekti turyzmolohii [Construction of highways in the aspect of tourism]. Ekonomika $i$ suspilstvo,15, 124-129. Retrieved from: https:/leconomy and society.in.ua/journals/15_ukr/20.pdf [inUkrainian]. 
3. Zalunina O. M. (2018). Inter sectoral balance of construction complexas a factor of territory development. International Journal of Modern Researchin Engineering and Technology, 3, 1, 68-74 [inUkrainian].

4. Butko M. P. \& Alieshuhina N. O. (2011). Rozvytok merezhi shliakhi v avtomobilnoho spoluchennia ta y ii rol u zmitsnenni turystychnoho potentsialu Ukrainy [Development of roads network and its role in Strengthening of Tourist Potential of Ukraine]. Rehionalna ekonomika, 2, 23-33. Retrieved from: http://nbuv.gov.ua/UJRN/regek_2011_2_5[inUkrainian].

5. Kanwal S., Rasheed M. I., Pitafi A., Pitafi A. \&Ren M.(2020) Road and transport infrastructure development and community support for tourism: The role of perceived benefits, and community satisfaction, Tourism Management, 77, 104014, DOI: 10.1016/j.tourman.2019.104014 [inEnglish]

6. Mirabueno J. \&Yujuico E. (2014).Pavingthe way for Philippine tourism via interagency collaboration on road networks. Transport Policy, 36, 306-315, DOI: 10.1016/j.tranpol.2014.10.002

7. Denstadli J. \& JacobsenJ. (2014). The long and winding roads: Perceived quality of scenic tourism routes, Tourism Management, 32, 4, 780-789, DOI: 10.1016/j.tourman.2010.06.014

8. Antonson H. \& Jacobsen J.Kr. St. (2014).Tourism development strategy or just brown signage? Comparing road administration policies and designation procedures for official tourism routes in two Scandinavian countries, LandUsePolicy, 36, 342-350, DOI: 10.1016/j.landusepol.2013.09.003.

9. Rosselló J. \& Saenz-de-Miera O. (2011).Road accidents and tourism: The case of the Balearic Islands (Spain). Accident Analysis \&Prevention, 43, 3, 675-683.

10. Bozhuk T. I. (2011). Rekreatsiino-turystychni destynatsii: teoriia, metodolohiia, praktyka [Recreational and tourist destinations: theory, methodology, practice]: avtoref. dys. d-raheohr. nauk: 11.00.11. Lviv, 2014, 40 p. [inUkrainian].

11. Klapchuk O. O. (2011). Turystychno-rekreatsiini resursy Lvivskoi oblasti: terytorialna dyferentsiatsiia, otsinka, napriamky vykorystannia [Tourist and recreation resources of lviv region: territorial differentiation, evaluation, way soft utilization]: avtoref. ... dys. kand. heohr. nauk: 11.00.02. Lviv[inUkrainian].

12. Ambitnyi plan remontu dorih u 2020 rots in a Lvivshchyni [Ambitious road repair plan in 2020 in Lviv region]. Ukravtodor. Sluzhba avtomobilnykh dorih u Lvivskii oblasti (2020). Retrieved from: https://lv.ukravtodor.gov.ua/press/news/ ambitnyi_plan_remontu_dorih_u_2020_rotsi_na_lvivshchyni.html[inUkrainian].

13. Postanova Kabinetu Ministriv Ukrainy № 726 vid 16 veresnia 2015 roku «Pro provedennia eksperymentu $v$ Odeskii, Volynskii, Lvivskiita Chernivetskii oblastiakh z finansovoho zabezpechennia rekonstruktsii, potochnoho remontu avtomobilnykh dorih zahalnoho korystuvannia derzhavnoho znachennia» [Resolution of the Cabinet of Ministersof Ukraine "About carrying out experiment in Odessa, Volyn, Lviv and Chernivtski regions on financial providing reconstruction, current repairs public roads of state importance»]. Verkhovna Rada Ukrainy (2021). Retrieved from: https://zakon.rada.gov.ua/laws/show/7262015-\%D0\%BF\#Text[inUkrainian]. 
14. «Polskyi kredyt» - realizatsiia Kontraktu [«Polish Credit» - implementation of the Contract]. Ukravtodor. Sluzhba avtomobilnykh dorih u Lvivskii oblasti (2020) Retrieved from: https://lv.ukravtodor.gov.ua/press/news/polskyi_kredyt_realizatsiia_kontraktu.html[inUkrainian].

15. Na remont dorih Lvivshchyny tsohorich vytratiat maizhe $1 \mathrm{mlrdhrn}$. [This year almost UAH 1 billion will be spent on road repairs in Lviv region]. Zaxid. net (2020). Retrieved from: https://zaxid.net/na_remont_dorig_lvivshhini_tsogorich_ vitratyat_mayzhe_1_mlrd_grn_spisok_n1513272[inUkrainian].

Стаття надійшла до редакиії 31.05.2021

Посилання на статтю: Періг Т.В. Сучасне будівництво і ремонт доріг у Львівській області як чинник розвитку туризму // Розвиток методів управління та господарювання на транспорті: Зб. наук. праць, 2021. № 2 (75). C. 132-143. DOI 10.31375/2226-1915-2021-2-132-143.

Articlereceived 31.05.2021

Reference a JournalArtic: Perih, Tetiana. (2021). Modern construction and reconditioning of the highways in Lviv district as the main factor of tourism development. Deve-lopment of management and entrepreneurship methods on transport. 2 (75), 132-143. DOI 10.31375/2226-1915-2021-2-132-143. 